\title{
PENGUATAN SEKTOR MIKRO TERHADAP PEMBIAYAAN AL-QARDH AL-HASAN DI BANK SYARIAH MANDIRI CABANG LOMBOK TIMUR
}

\author{
Baiq Isniarti \\ Islam Institut Agama Islam Negeri Mataram \\ hjbaiqisniarti@gmail.com
}

\begin{abstract}
Referring to the economy of West Nusa Tenggara Province, East Lombok Regency is an area that is considered very suitable for the development of UMKM. There are several reasons that can be put forward, including the very weak economic condition of the community and the very dense population growth according to the community to find their own business to fulfill their daily needs. With this situation, UMKM based businesses have more potential than industrial-based economic business activities. In addition, the socio-religious factors of the community, the majority of which are Muslim, are 90\%, as well as the large number of religious educational institutions such as Islamic boarding schools and madrasas that create religious emotional closeness so that they can use Islamic bank products, particularly al-Qardh al-Hasan financing for the development of small and micro businesses. The author can formulate the problem in this study as follows: a) How is the implementation of al-Qardh alHasan financing at PT. East Lombok Branch of Bank Syariah Mandiri for UMKM?, b) How is the contribution of al-Qardh al-Hasan financing to the strengthening of Micro Enterprises in East Lombok Regency? This research is a field research, The nature of descriptive research. The implementation of Qardhul Hasan financing at Bank Syariah Mandiri East Lombok. Branch is applied in a program called the Umat Partner Program namely: Community Education Program (Economic Empowerment) and Sympathy People (Social Concern), in its development includes productive and consumptive economic activities, social community including education, bealth. Broadly speaking, this program is divided into economic empowerment activities (manifested in the form of providing Qardhul Hasan loans in the form of business or investment and consumptive capital) and social activities (donations). In the process of implementing this financing, Bank Syariah Mandiri East Lombok Branch provides many conveniences, especially in the process of submitting and paying installments, so that customers feel comfortable with this financing service. And the contribution of Qardhul Hasan funds for micro-businesses customers is an increase in income which is an average of $\mathrm{R}$. 400,000, - or about 66\%. This increase in income has an effect on the increase in net income (after installments deducted) for customers who previously only earned an average income of $\mathrm{R}$. 505,000, - to an average of $\mathrm{R}$. 775,000, - per month. With an increase in operating income by $66 \%$, it means that Qardhul Hasan financing has contributed Rp. 235,000, - or 18\% for the poor to be above the poverty line.
\end{abstract}

Keywords: Islamic Bank, Micro Sector, Al-Qardh Al-Hasan Financing

\begin{abstract}
Abstrak : Merujuk pada perekonomian Provinsi Nusa Tenggara Barat, Kabupaten Lombok Timur merupakan daerah yang dinilai sangat cocok untuk pengembangan UMKM. Ada beberapa alasan yang bisa dikemukakan di antaranya adalah kondidi perekonomian masyarakat yang sangat lemah dan pertumbuhan penduduk yang sangat padat menurut masyarakat untuk mencari usaha sendiri dalam memenuhi kebutuhan hidup. Denga situasi ini, usaha yang berbasis UMKM lebih berpotensi dibandingkan dengan kegiatan usaha
\end{abstract}

Islamika : Jurnal Keislaman dan Ilmu Pendidikan

Volume 3, Nomor 2, Juli 2021; 178-199

https:// ejournal.stitpn.ac.id/index.php/islamika 
ekonomi berbasis industri. Selain itu faktor sosial keagamaan masyarakat yang mayotitas beragama Islam dengan prosentase $90 \%$, serta banyaknya lembaga pendidikan keagamaan seperti pondok pesantren dan madrasah yang memunculkan kedekatan emosional keagamaan sehingga dapat menggunakan produk-produk bank syariah, khususnya pembiayaan al-Qardh al-Hasan untuk pengembangan usaha kecil mikro. Penulis dapat merumuskan masalah pada penelitian ini sebagai berikut: a) Bagaimana implementasi pembiayaan al-Qardh al-Hasan di PT. Bank Syariah Mandiri Cabang Lombok Timur bagi UMKM?; b) Bagaimana kontribusi pembiayaan al-Qardh al-Hasan terhadap penguatan Usaha Mikro di Kabupaten Lombok Timur? Penelitian ini adalah Penelitian lapangan (field Research). Sifat penelitian deskriptif. Pelaksanaan pembiayaan Qardhul hasan di Bank Syariah Mandiri Cabang Lombok Timur diaplikasikan dalam program yang disebut dengan Program Mitra Umat yaitu : Program Didik Umat (Pemberdayaan Ekonomi) dan Simpati Umat (Kepedulian Sosial), dalam pengembangannya mencakup kegiatan ekonomi produktif maupun konsumtif, sosial kemasyarakatan meliputi pendidikan, kesehatan. Secara garis besar program ini terbagi dalam kegiatan pemberdayaan ekonomi (diwujudkan dalam bentuk pemberian pinjaman Qardhul hasan berupa modal usaha atau investasi dan konsumtif) dan kegiatan sosial (sumbangan). Dalam proses pelaksanaan pemberian pembiayaan ini Bank Syariah Mandiri Cabang Lombok Timur banyak memberikan kemudahan-kemudahan terutama dalam proses pengajuan dan pembayaran angsuran, sehingga nasabah merasa nyaman dengan pelayanan pembiayaan ini. Dan Kontribusi dana Qardhul hasan bagi Usaha Mikro nasabah adalah adanya peningkatan pendapatan yang rata-ratanya adalah sebesar Rp. 400.000,- atau sekitar 66\%. Dengan adanya kenaikan pendapatan ini berpengaruh terhadap meningkatnya pendapatan bersih (setelah dipotong angsuran) para nasabah yang sebelumnya hanya memperoleh pendapatan rata-rata sebesar Rp. 505.000,- menjadi rata-rata sebesar Rp. 775.000,- perbulan. Dengan adanya peningkatan pendapatan usaha sebesar $66 \%$ berarti pembiayaan Qardhul hasan telah memberikan kontribusi sebesar Rp. 235.000,- atau 18\% kepada masyarakat miskin untuk berada diatas batas garis kemiskinan.

Kata Kunci: Bank Syariah, Sektor Mikro, Pembiayaan Al-Qardh Al-Hasan

\section{PENDAHULUAN}

Perkembangan Perbankan Syariah diikuti dengan pertumbuhan sektor Usaha Mikro Kecik Menengah (UMKM) yang sejauh ini telah menunjukkan geliat yang sanag baik. Wajar bila sektor ini menjadi fokus pembiayaan Perbankan Syariah. Sektor UMKM bahkan mampu menopang pertumbuhan ekonomi nasional. Sektor ini juga yang menjadi pendorong perekonomian saat krisi melanda. Sama sperti UMKM, Perbankan Syariah yang selama ini ditepikan justru menunjukkan eksistensinya saat krisis terjadi. Potensi besar dari UMKM tersebut menjadi salah satu pon penting bagi bank-bank syariah untuk menyalurkan pembiayaanya.

Bukan hanya PT. Bank Muamalat Indonesia yang peduli terhadap perkembangan UMKM, PT. Bank Syariah Mandiri termasuk yang gencar ubtuk 
meraih pangsa pasar UMKM. Pada awal Tahun 2009, PT. Bank Syariah Mandiri tetap mempertahankan porsi dana penyaluran untk UMKM sebesar 57\%. Kendati demikian, PT. Bank Syariah Mandiri berharap bisa meningktakna pertumbuhan hingga 80\%. Pada tahun 2005, posisi pembiayaan UMKM oleh PT. Bank Syariah Mandiri mencapai Rp. 3,26 triliun. Pada 2006 mengalami kenaikan Rp. 4,83 triliun. Pada periode 2007-2008 telah mencapai Rp. Rp. 7,72 triliun sehingga total pembiayaan mencapai Rp. 13 triliun. ${ }^{1}$

Upaya Bank Syariah dalam mengoptimalkan UMKM terdapat dalam model akad (transaksi) Tabarru', dan produk pembiayaan al-Qardh al-Hasan termasuk dalam akad Tabrru', yaitu segala macam perjanjian yang menyangkut not-profit transaction (transaksi nirlaba). Transaksi ini pada hikakatnya bukan transaksi bisnis untuk mencari keuntungan komersial. Akad tabarru' dilakukan dengan tujuan tolong menolong dalam rangka berbuat kebaikan. ${ }^{2}$ Jelasnya akad Tabarru' adalah sematamata untuk menolong orang-orang yang membutuhkan dana tanpa mengharapkan imbalan sedikitpun, apalagi dalam bentuk prosentase (bunga).

Keberadaan produk al-Qardh al-Hasan adalah salah satu solusi untuk mengoptimalkan dana zakat (infaq dan Shadaqah). Ulama sangat menyadari bahwa pensyariatan Zakat Infaq dan Shadaqah (ZIS) adalah salah satu terobosan besar yang ditawarkan Islam dalam sistem interaksi sosial-ekonomi sepanjang sejarah umat manusia sebagai solusi untuk usaha mengentaskan kemiskinan, menumbuhkan solidaritas sosial antar sesama anggota masyarakat, mengurangi kesenjangan, dan yang terpenting adalah sebagai investasi modal bagi para pelaku (mustabik) dalam mengatasi berbagai kesulitan hidup. ${ }^{3}$

Pembiayaan al-Qardh al-Hasan, meski bukan sebuah produk komersil namun sangat penting untuk diterapkan dalam jumlah yang proposional karena al-Qardh alHasan adalah salah satu ciri Perbankan Syariah. Penerapan al-Qardh al-Hasan dalam Perbankan Syariah lebih strategis karena sebagi salah satu bentuk kontribusi dalam

\footnotetext{
${ }^{1}$ www.seputarindonesiia.com: Raih Dukungan Bank Syariah, akses tanggal 7 Januari 2020

2 Adiwarman Karim, Bank Islam: Analsisi Fiqih dan Keuangan, Cet. 1, (jakarta: IIIT Indonesia, 2003), 68.

${ }^{3}$ Mohammad Daud Ali, Sistem Ekonomi Islam Zakat dan Wakaf, Cetakan 1 (Jakarta: UI Press 2006), 56
} 
membangun perekonomian umat, tentu bukan hanya dari praktik pembiayaan namun juga dari segi pengembangan usaha.

Kabupaten Lombok Timur adalah salah satu kabupeten di Provinsi Nusa Tenggara Barat. Berdasarkan laporan Dinas Perekonomian Provinsi Nusa Tenggara Barat, Kabupaten Lombok Timur merupakan daerah yang dinilai sangat cocok untuk pengembangan UMKM. Ada beberapa alasan yang bisa dikemukakan di antaranya adalah kondisi perekonomian masyarakat yang sangat lemah dan pertumbuhan penduduk yang sangat padat menurut masyarakat untuk mencari usaha sendiri dalam memenuhi kebutuhan hidup. Denga situasi ini, usaha yang berbasis UMKM lebih berpotensi dibandingkan dengan kegiatan usaha ekonomi berbasis industri. Selain itu faktor sosial keagamaan masyarakat yang mayoritas beragama Islam dengan prosentase $90 \%$, serta banyaknya lembaga pendidikan keagamaan seperti pondok pesantren dan madrasah yang memunculkan kedekatan emosional keagamaan sehingga dapat menggunakan produk-produk bank syariah, khususnya pembiayaan al-Qardh al-Hasan untuk pengembangan usaha kecil mikro.

\section{KAJIAN PUSTAKA}

\section{Bank Syariah}

Bank Syariah merupakan suatu lembaga keuangan yang berfungsi sebagai organisasi perantara antara yang berkelebihan dana dan yang kekurangan dana yang dalam menjalankan aktifitasnya harus sesuai dengan prinsip-prinsip Islam. Bank Syariah atau Bank Islam, berfungsi sebagi suatu lembaga intermediasi (intermediary instittution), yaitu mengerahkan dana dari masyarakat dan menyalurkan kembali danadana tersebut dalam bentuk pembiayaan. ${ }^{4}$ Berdasarkan UU No. 21 Tahun 2008 pasal 4 tentang Perbankan Syariah disebutkan bahwa bank Syariah menpunyai fungsi menghimpun dan menyalurkan dana masyarakat. ${ }^{5}$ Fungsi bank syariah secara umum terbagi menjadi dua yaitu fungsi sebagai slembaga bisnis (Tijarah) dan fungsi sosial

${ }^{4}$ Darmawan M. Rahardjo, Islam dan Transformasi Sosial Ekonomi, Lembaga Studi Agama dan Filsafat (LSAF), Jakarta, 1999, 410.

${ }^{5}$ Undang Undang Nomor 21 Tahun 2008 Tentang Perbankan Syariah 
(Tabarru). ${ }^{6}$ Fungsi bisnis bank syariah terwujud melalui fungsi sebagai manajer investasi, investor, dan fungsi sebagai penyedia jasa keuangan, sedangkan fungsi sosial (Tabrru') diwujudkan melalui zakat, infaq, shadakah dan wakaf (ZISWAF). ${ }^{7}$

Fungsi-fungsi lembaga keuangan syariah (Bank Syariah) dapat dijabarkan sebagai berikut: ${ }^{8}$

a. Bank Syariah sebagai Lembaga Bisnis

1) Bank Syariah sebagai Manajer Investasi

Sebagai manajer investasi, bankan syariah berperan dalam pengelolaan dana yang dihimpun dari nasabah. Bank syariah berkewajiban mengelola dan yang terhimpun dengan hati-hati, profesional, seta transparan. Besar kecilnya pendapatan (bagi hasil) yang diterima oleh pemilik dana (nasabah/deposan) sangant bergantung pada keahlian, kehati-hatian, dan profesionalisme dari bank syariah. Setiap dana yang terhimpun dari nasabah harus dialokasikan kepada sektor-sektor yang akan memberikan implikasi langsung kepada pemilik dana.

Fungsi manajer invesatsi ini dilakukan dengan cara menghimpun dana melalui prinsip wadiah yad dhamanah dan atau prinsip mudharabah mutlaqah. Prinsip wadiah yad dhamananh bisa dalam bentuk simpanan giro wadiah atau tabungan mudharabah, sedangkan prinsip mudharabah mutlaqah bisa dalam bentuk tabungan mudharabah atau deposito mudharabah. Setiap dana yang terhompun dari nasabah, khususnya dalam bentuk dana mudharabah, harus kembali disalurkan dalam bentuk pembiayaan kepada disalurkan dalam bentuk pembiayaan kepada sektor-sektor yang produktif agar dana yang dihimpun tersebut dapat menghasilkan bagi pemilik dana/nasabah. Bank syariah tidak sepantasnya menghimpun dana mudharabah apabila tidak mampu menyalurkan dana tersebut pada sektor yang produktif karena bagi hasil yang akan diterima oleh pemilik dana akan semakin kecil.

\footnotetext{
${ }^{6}$ Adwarman Karim, Bank Islam: Analisis Fiqib dan kenangan, 68.

${ }^{7}$ Rizal Yahya, Aji Erlangga, Ahim Abdurrahim, Akuntansi Perbankan Syariah Teori dan Praktik. Kontemporer, Salemba Empat, Jakarta 2009. 54

${ }^{8}$ Ibid., 55-56
} 
2) Bank Syariah sebagai investor

Bank syariah akan berhasil menghimpun dana dalam bentuk wadiah yad dhamanah, mudharabah mutlaqah, atau dana lain (modal sendiri) kemudian dikumpulkan menjadi satu dalam bentuk pooling dana.

Berbagai macam dana yang dihimpun dan dicampur dalam pooling dana inilah yang kemudian digunakan oleh bank syariah yang berfungsi sebagai investor untuk disalurkan kepada sektor-sektor yang tidak bertentangan dengan syariah. Umumnya penyaluran dana (investasi) oleh bank syariah dilakukan melalui tiga jenis penyaluran:

a) Prinsip Bagi Hasil, yaitu instrumen penyaluran dana kepada sektor-sektor produktif dengan menggunakan produk-produk pembiayaan mudharabah dan musyarakah.

b) Prinsip Ujrah, yaitu sarana penyaluran dana melalui produk-produk pembiayaan Ijarah dan ijarah muntahiyah bittamlik.

c) Pinsip-prinsip jual neli, yaitu penyaluran pendanaan melalui produk-produk pembiayaan murabahah, salam dan salam paralel, istishna dan istishna paralel.

Selain itu investasi bisa juga disalurkan melalui pembentukan perusahaan atau akusisi pengendalian atau kepentingan lain dalam rangka mendirikan perusahaan, memperdagangkan produk dan investasi atau memperdagangkan saham yang dapat diperjualbelikan. Keuntungan dari setiap investasi yang dilakukan oleh bank syariah kemudian dibagikan kepada pemilik dana (nasabah/deposan) berdasarkan akad yang telag disepakati antara bank syariah dengan pihak pemilik dana.

Penyaluran dana melalui beberapa instrumen dan mekanisme tersebut menegaskan fungsi bank syariah sebagai investor. Fungsi ini harus dijalankan dengan maksimal agar bank syariah mendapatkan keuntungan sehingga keuntungan yang didapat para pemilik dana menjadi maksimal juga.

3) Bank Syariah sebagai Penyedia Jasa Keuangan

Fungsi ini tidak jauh berbeda dengan fungsi yang telah dijalankan oleh bank konvensional (non-syariah). Bank syariah juga bisa memberikan layanan transfer, 
RTGS (Real Time Gross Settlement), kliring, inkaso, payroll (pembayaran gaji), jasa pembayaran telpon, listrik dan lain sebagainya, namun tetap harus memperhatikan prinsip-prinsip syariah dan tidak melanggar kaidah-kaidah syariah yang telah ditetapkan. Hampir semua layanan jasa bank konvensional bisa juga diberikan oleh bank syariah, misalnya bank garansi, letter of credit, mobile banking, net banking, dan lain sebagainya. Ini bisa dilakukan karena secara sistem teknologi bank syariah juga telah mengadopsi teknologi-teknologi mutakhir dan maju sesuai dengan perkembangan jaman.

\section{Pembiayaan}

a. Pengertian Pembiayaan

Pembiayaan atau financing, yaitu pendanaan yang diberikan oleh suatubank kepada pihak lain untuk mendukung investasi yang telah direncanakan, baik dilakukan sendiri maupun lembaga. Dalam kaintannya dengan pembiayaan pada bank syariah atau istilah teknisnya disebut dengan aktiva produktif. Menurut ketentuan Bank Indonesia aktiva produktif adalah penggunaan dana bank syariah baik dalam rupiah maupun valuta sing dalam bentuk pembiayaan, piutang, al-Qardh, surat berharga syariah, penempatan, penyertaan modal, penyertaan modal sementara, komitmen dan kontijensi pada rekening administratif serta Setifikat Wadi'ab Bank Indonesia (Peraturan Bank Indonesia Nomor 5/7/PBI/2003 tanggal 19 Mei 2003.

b. Falsafah Pembiayaan

Dalam pelaksanaan pembiayaan, bank syariah harus memenuhi dua aspek, sebagai berikut: ${ }^{10}$

1) Aspek syariah, yang berarti dalam setiap realisasi pembiayaan kepada para nasabah, bank syariah harus tetap berpedoman pada syariat Islam yang antara lain yidak mengandung unsur maysir, gharar dan riba.

2) Aspek ekonomi yang berarti mempertimbangkan perolehan keuntungan bagi bank syariah maupun nasabah itu sendiri.

\footnotetext{
${ }^{9}$ Muhammad, Manajemen Pembiayaan Bank Syariah, (Yogyakarta: UPP YKPN, 2005), 16.
}

${ }^{10}$ Muhammad, Manajemen Dana Bank Syari'ah, (Yogyakarta: Ekonosia, 2004), 203 


\section{Konsep Dana Al-Qardh dan Al-Qardhul Al-Hasan}

a. Pengertian

Al-Qardh adalah pemberian harta kepada orang lain yang dapat ditagih atau diminta kembali atau dengan kata lain meminjamkan tanpa mengharapkan imbalan. Pemberian dana al-Qard kepada nasabah ini berdasarkan pada kebutuhan dana yang sifatnya mendesak. Sedangkan al-Qardh al-Hasan adalah Pinjaman lunak ini di berikan atas dasar kewajiban sosial semata dimana nasabah tidak dituntut untuk mengembalikan apapun kecuali modal. Pemberian dana al-Qardh al-Hasan ini didasarkan pada kewajiban untuk membantu masyarakat lemah berupa modal untuk membangun atau mengembangkan. ${ }^{11}$

b. Perbedaan al-Qardh dan al-Qardh al-Hasan

Perbedaan antara Al-qardh dan al-Qardh al-Hasan adalah pada sumber dana dan penggunaan dananya. Dalam aplikasi perbankan, dana al-Qardh al-Hasan diberikan kepada masyarakat lemah berupa modal untuk membangun dan mengembangkan usahanya. Sedangkan dana al-Qardh diberikan kepada nasabah sebagai produk pelengkap atas terbukti loyalitas dan bonafiditasnya, yang membutuhkan dana talangan segera untuk masa yang relatif pendek, kemudian nasabah tersebut akan mengembalikan secepatnya sejumlah uang yang dipinjamkan. Dalam perbankan, pinjaman dana al-Qardh ini dapat berupa pinjaman tunai dari produk kartu kredit syariah, dimana nasabah diberikan keluasan kepada nasabah untuk menarik uang tunai milik bank di ATM, kemudian nasabah tersebut mengembalikannya sesuai waktu yang ditentukan. ${ }^{12}$

c. Sumber Dana al-Qard dan al-Qardh al-Hasan

Menurut Muhammad Syafi'I Antonio, bahwa dana al-Qardh dan al-Qardh alHasan dapat dari beberapa sumber, yaitu: ${ }^{13}$

1) Al-Qardh yang diperlukan untuk membantu keuangan nasabah secara cepat dan berjangka pendek, maka sumber dana dapat diambil modal bank.

11 Muhammad Syafii Antonio, Bank Syariah, 131. Serta lihat juga Karmaen Perwataatmadja dan Muhammad Syafii Antonio, ada dan Bagaimana Bank Islam, (yogyakarta: PT. Dana Bhakti Prima Yasa, 1999), 33.

${ }_{12}$ Muhammad Syafii Antonio, Bank Syariah., 131

13 Ibid., 133. 
2) Al-Qardh al-Hasan yang diperlukan untuk membantu usaha sangat kecil dan keperluan sosial, maka sumber dana dapat berasal dari zakat, infaq, dan shadaqqah. Selain itu, ulama dan praktisi perbankan melihat adanya sumber lain untuk alQardh al-Hasan yaitu dari pendapatan-pendapatan yang diragukan seperti bunga atas jaminan L/C di bank asing dan sebagainya.

d. Perbedaan Dana al-Qardh al-Hasan

Berdasarkan dengan PSAK 101 tentang Penyajian Laporan Keuangan Syariah, bahwa komponen laporan penggunaan dana kebjikan meliputi: ${ }^{14}$

1) Dana kebijakan produktif

2) Sumbangan

3) Penggunaan lain untuk kepentingan umum

Adapun penggunaan dana al-Qardh al-Hasan yang bersumber dari zakat, maka yang menjadi sasaran penyaluran dana tersebut adalah para asnaf yang didasarkan pada Firman Allah dalam Surah at-Taubah ayat $60:^{15}$

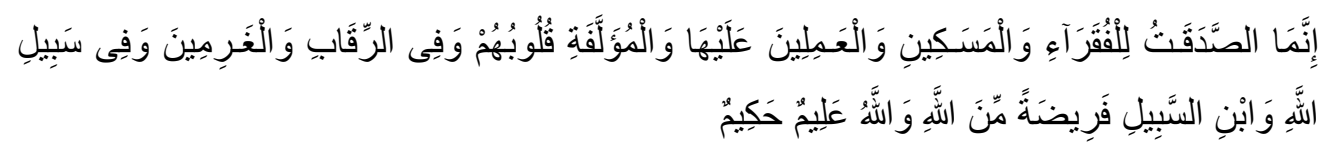

Artinya : "Sesungguhnya zakat-zakat, hanyalah untuk orang-orang fakir, orang-orang miskin, pengurus-pengurus zakat, para muallaf yang dibujuk hatinya, untuk (memerdekakan) budak, orang-orang yang berutang, untuk, jalan Allah dan orang-orang yang sedang dalam perjalanan, sebagai sesuatu ketetapan yang diwajibkan Allab: dan Alllah Maha Mengatahui lagi Maha Bijaksana.”

Sebagaimana dengan penggunaanya, menurut Yusuf al- Qardhawi seperti yang dikutip oleh Didin Hafiduddin mengemukakakn bahwa pemerintah Islam boleh membangun pabrik-pabrik atau perusahaan dari uang zakat untuk kemudia

14 Rifki Muhammad, AKuntansi Kenangan Syariah: Konsep dan Implementasi PSAK Syariah (Yogyakarta: P3EI Press, 2008), 129-155.

15 Al-Qur'an dan Terjemahnya, Yogyakarta: PT. Dana Bhakti Wakaf, 1992. 
kepemilikan dan keuntungannya bagi kepentingan fakir miskin. ${ }^{16}$ Sehingga dana zakat tersebut menjadi dana yang produktif.

Penyaluran dana zakat produktif dapat dilakukan melalui: ${ }^{17}$

1) Pemberian modal kerja dan pendampingan

2) Penjaminan bagi usaha kecil yang bermasalah

3) Pendirian sektor produksi yang dikerjakan oleh masyarakat lemah

4) Dan usaha-usaha produktif lainya.

Sedangkan dana al-Qardh al-Hasan yang bersumber dari infaq dan shadaqah, maka dalam penyaluranya tidak ditentukan penerimanya. ${ }^{18}$ Menurut Mazhab Syafi'i dan Mazhab Hambali bahwa infak hanya diberikan kepada orang-orang yang hidupnya susah baik muslim maupu non muslim. Dan menurut Mazhab Hanafi, infak itu hanya diberikan kerabat dekat, anak yatim, dan orang miskin, atau orang yang pada umumnya mengalami kesulitan ekonomi. ${ }^{19}$

Begitu juga dengan orang-orang yang berhak menerima dana yang berasal dari shadaqah, maka penyaluranya tidak terbatas pada penerima yang masuk dalam kelompok delapan asnaf. Sesuai dengan Sabda Rasulullah SAW yang diriwayatkan oleh Abu Dawud dan al-Hakim ${ }^{20}$ bahwa sedekah sunnah itu boleh diberikan kepada orang selain delapan asnaf yaitu istri, anak, pelayan dan orang lain yang dianggap lebih baik untuk menerimanya.. ${ }^{21}$

16 Didin Hafiduddin, Zakat dalam Perekonomian Modern, cet. 1, (jakarta: Gema Insani Press, 2002) 134.

17 Mursyid, Mekanisme Pengumpulan Zakat, Infaq, dan Shadaqab: Menurut Hukum Syara' dan Undang Undang, (Yogyakarta: Magistra Insani Press, 2006) 87.

18 Rifki Muhammad, AKuntansi..., 434

${ }^{19}$ Ensiklopedi Hukum Islam, (Jakarta: PT. Ichtiar Bary Van Hoeve), 718.

20 Rasulullah saw bersabda: "Bersedekahlah kamu,." Lalu ada seorang laki-laki bertanya kepada Rasulullah saw: "Ya Rasulullah, saya mempunyai satu dinar uang." Rasulullah saw bersabda: "Sedekahkanlah untuk dirimu sendiri." Laki-laki itu berkata lagi: "Ada satu dinar yang lain ya Rasulullah.” Maka Rasulullah saw bersabda: Sedekahkanlah untuk istrimu”.Kemudian dia berkata lagi: "Masih ada satu dinar lagi ya Rasulullah",maka Rasulullah saw bersabda: "Sedekahkanlah untuk anakmu."kata laki-laki itu: "Masih ada satu dinar lagi”.Rasulullah saw berabda: "Sedekahkanlah untuk pelayanmu."Ia berkata lagi: “Ada satu dinar lagi.”'Rasulullah bersabda: “Terserah padamu, engkau lebih mengetahui ke mana yang lebih baik."

${ }^{21}$ Ensiklopedi Hukum Islam, 1618. 


\section{Konsep Usaha Kecil Mikro dan Menengah}

Dalam kategori kelompok usaha dapat dibagi menjadi tiga kelompok, yaitu kelompok usaha kecil, menengah dan usaha besar.. Dalam penelitian ini, pokok bahasan adalah usaha kecil. Yang dimaksud kelompok usaha kecil, yaitu suatu usaha yang dikelola oleh pengusaha miskin, dan usaha homogen. Mereka pada umumnya bergerak dalam bidang usaha yang bersifat tradisional dan usaha kecil informal. Yang dimaksud dengan usaha kecil tradisional adalah usaha yang menggunakan alat produksi sederhan dan telah digunakan secara turun menurun dan banyak ditentukan oleh faktor alam. ${ }^{22}$ Sedangkan untuk usaha kecil informal adalah usaha yang belum terdaftar, berlum tercatat, dan belum berbadan hukum, antara lain, petani penggarap, industri rumah tangga, pedagang asongan, pedagang keliling, pedagang kaki lima, dan pemulung. ${ }^{23}$

\section{METODE PENELITIAN}

Jenis penelitian ini adalah penelitian lapangan (field research) yang data dan informasinya dari kegiatan di lapangan kerja penelitian, dapat pula disebut sebagai penelitian empiris. ${ }^{24}$ Penelitian ini bertujuan untuk mempelajari secara intensif tentang latar belakang keadaan yang terjadi pada saat tertentu dan interaksi lingkungan suatu unit sosial: individu, kelompok, lembaga atau masyarakat.

Sifat penelitian ini adalah penelitian deskriptif, yaitu penelitian yang bermaksud untuk membuat pencandraan (deskripsi) mengenai situasi-situasi atau kejadian-kejadian. ${ }^{25}$ Penelitian dengan desain deskriptif mengutamakan beberapa metode riset yang salah satunya adalah metode studi kasus yaitu riset yang menghendaki suatu kajian yang rinci, mendalam, menyeluruh atas obyek tertentu yang bisanya relatif kecil selama kurun waktu tertentu termasuk lingkungannya. ${ }^{26}$

${ }^{22}$ Kwik Kian Gie, Praktek Bisnis dan Prientasi Ekonomi Indonesia, (Jakarta: PT Gramedia Pustaka Utama \& Sekolah Tinggi Ilmu Ekonomi IBII, 1998), 218

${ }^{23}$ B.N. Marbun, Manajemen Perusahaan Kecil, (Jakarta: Pustaka Binaman Pressindo, 1996) 128.

${ }^{24}$ Supardi, Metodologi Penelitian Ekonomi Bisnis, (Yogyakarta: UII Press, 2005), 34.

${ }^{25}$ Sumadi Suryabrata, Metodologi Penelitian, (Jakarta: Raja Grafindo Persada, 1997), 18.

${ }^{26}$ Husein Umar, Metode Riset Bisnis, (Jakarta: PT. Gramedia Pustaka Utama, 2003), 42. 
Dalam penelitian ini, pendekatan yang digunakan adalah pendekatan fenomenologi. Isitilah "fenomenologi" sering digunakan anggapan umum untuk menunjuk pada pengalaman subjektif dari berbagai jenis dan tipe subjek yang ditemui. Fenomenolgi diartikan sebagai pengalaman subjektif atau pengalaman fenomenologikal. Sedangkan yang ditekakan dalam fenomenologi adalah pemahaman terhadap pengalaman subjektif atas peristiwa dan kaitan-kaitan yang melingkupi subyek. ${ }^{27}$

\section{Teknik Pengumpulan Data}

a. Observasi

Observasi $^{28}$ yaitu mengamati perilaku seseorang selama beberapa waktu tanpa melakukan manipulasi atau pengedalian serta mencatat penemuan yang memungkinkan atau memenuhi syarat digunakan penafsiran lebih lanjut. Dalam observasi pengamatan yang dilakukan peneliti bukan hanya sekedar melihat saja melainkan mencatat informasi yang diperoleh. Hal ini perlu dilakukan peneliti karena daya ingat manusai terbatas untuk menyimpan semua informasi tentang apa yang akan diobservasi.

b. Dokumentasi

Dokumenntasi yang digunakan peneliti adalah mencari dan mendapatkan data-data primer dengan melalui data-data dari prasasti-prasasti, naskah-naskah kearsipan, data gambar/foto/blue print dan lain sebagainya. ${ }^{29}$ Dengan adanya data tersebut, maka peneliti dapat memecahkan masalah penelitian.

Adapun sumber data yang diambil dan digunakan dalam penilitian ini adalah:

Data primer adalah data yang dikumpulkan langsung dari responden melalui daftar pertanyaan yang telah dijawab oleh responden melalui angket maupun wawancara. Pengumpulan data ini dilakukan terhadap individu-individu yang menjadi nasabah pembiayaan al-Qardh al-Hasan pada PT. Bank Syariah Mandiri Cabang

27 "Fenomenologi", http://bambangsukmawijaya.wordpress.com/2007/12/07fenomenolgidan-intraksi-simbolik, diakses tanggal 7 Januari 2020.

${ }^{28}$ Jams A. Black \& Dean J. Champion, Metode dan Maslab Penelitian Sosial, (Bandung: Rapika Aditama, 1999), 286

${ }^{29}$ Supardi, Metodologi Penelitian Ekonomi dan Bisnis, (Yogyakarta: UII Press, 2005), 122 
Lombok Timur untuk membuat usaha maupun yang akan menambah modal usahanya. Pengumpulan data melalui angket difokuskan pada nasabah yang mendapat pinjaman selama tahun 2016 sampai tahun 2020.

Data sekunder yaitu data yang diperoleh dari informasi maupun dokumen seperti laporan tahunan yang berkenaan nasabah al-Qardh al-Hasan, data-data nasabah al-Qardh al-Hasan, dan jumlah dana yang disalurkan selama tahun 2016 sampai dengan 2020.

Analisis data kualitatif adalah upaya yang dilakukan dengan jalan bekerja dengan data, mengorganisasi data, memilah-milah menjadi satuan yang dapat dikelola, mensintesiskannya, mencari dan menemukan pola, menemukan apa yang penting dan apa yang dipelajari, dan memutuskan apa yang dapat diceriterakan kepada orang lain. ${ }^{30}$ Untuk analisa data kualitatif, maka pola berfikir yang digunakan untuk menganalisa data adalah induktif. Pola fikir induktif adalah untuk menganalisa datadata yang bersifat khusus untuk ditarik kepada yang umum. ${ }^{31}$

Sedangkan tahapan-tahapan teknis analisa data dalam penelitin ini adalah sebagai berikut: ${ }^{32}$

\section{a. Editing}

Proses editing dilakukan setelah penulis mendapatkan data dari hasil wawancara dan dokumen-dokumen di lapangan.

b. Koding

Setelah melakukan editing, maka tahapan selanjutnya adalah melakukan koding yaitu usaha untuk mengklasifikasikan jawaban-jawaban para responden menurut macamnya. Dengan kata lain bahwa proses koding ini dilakukan untuk mengklasifikasikan jawaban-jawaban ke dalam kategori penting.

Setelah proses koding selesai dikerjakan, maka proses selanjutnya adalah melakukan proses penghitungan frekuensi data masing-masing kategori yang 2007), 248

${ }^{30}$ Lexy J. Moleong, Metodologi Penelitian Kualitatif, Edisi Revisi (Bandung: Rosda Karya,

${ }^{31}$ Deddy Mulyana, Metodologi Penelitian Kualitatif: Paradigma Baru Ilmu Komunikasi dan Ilmu Sosial Lainnya, (Bandung: Remaja Rosdakarya, 2004), 155.

32 Soeratno dan Lincolin Arsyad, Metodologi Penelitian Untuk Ekonomi dan Bisnis, Cet. Ke-4 Edisi Revisi, (Yogyakarta: UPP AMP YKPN, 2003), 127. 
kemudian dilanjutkan dengan proses tabulasi. Tahapan tabulasi ini adalah melakukan penyajian data dengan menampilkan data-data dalam bentuk narasi, tabel dan grafik yang disertai dengan analisa data-data tersebut.

\section{HASIL PENELITIAN}

\section{Sasaran Penyaluran Dana Qardhul hasan}

Distribusi dana Qardhul hasan, Bank Syariah Mandiri Cabang Lombok Timur menyalurkannya dalam dua model penyaluran yang dituangkan dalam Program Mitra Umat BSM yaitu:

a. Program Didik Umat (Pemberdayaan Ekonomi Produktif)

Program Didik Umat adalah upaya Bank Syariah Mandiri untuk mendidik dan memberikan kesempatan untuk para mustahik dalam mengembangkan usahanya. Bentuk pinjamannya adalah dana pinjaman produktif sebagai tambahan modal usaha untuk menghasilkan barang secara terus menerus atau juga membantu untuk meningkatkan produksi suatu barang.

b. Program Simpati Umat (Kepedulian Sosial)

Program Simpati Umat adalah bentuk tanggung jawab sosial Bank Syariah Mandiri terhadap lingkungan sekitarnya. Bentuk Dana sosial ini adalah penyaluran dana yang semata-mata hanya diperuntukkan bagi mereka yang membutuhkan untuk keperluan konsumsi atau juga untuk memenuhi kebutuhan yang mendesak. Untuk penyaluran dana sosial, pihak bank menyalurkan dana Qardhul hasan kedalam beberapa bentuk, yaitu:

1) Beasiswa sebesar Rp. 500.000 ,- per siswa/mahasiswa

2) Kesejahteraan bagi karyawan kontrak Bank Syariah Mandiri Cabang Lombok Timur, seperti biaya rumah sakit.

3) Sumbangan, yaitu pemberian dana kebajikan kepada masyarakat atau kelompok untuk kepentingan masyarakat setempat seperti, bantuan korban bencana alam, sumbangan untuk masjid, khitan massal, yayasan anak yatim, dan lain sebagainya. 
Adapun sasaran dari penyaluran dana Qardhul hasan ini adalah mereka yang tergolong dalam delapan asnaf. Penetapan penerima dana Qardhul hasan ini didasarkan pada sumber dana Qardhul hasan Bank Syariah Mandiri Cabang Lombok Timur yang bersumber pada zakat karyawan BSM di seluruh Indonesia dan . Dari kedelapan kelompok asnaf tersebut dibagi menjadi dua kelompok, yaitu:

1) Kelompok yang mendapatkan pinjaman produktif, yaitu:
a) Orang Fakir
b) Orang Miskin
c) Orang yang berhutang (gharimin)
d) Riqab

2) Kelompok yang mendapatkan bantuan dana sosial, yaitu:
a) Ibnu sabil
b) Orang yang sedang di jalan Allah SWT
c) Muallaf
d) Adapun persentase dari penyaluran dana Qardbul hasan di Bank Syariah Mandiri Cabang Lombok Timur dapat dilihat pada tabel di bawah ini:

Tabel. 2 Persentase Penyaluran Dana Qardhul hasan

\begin{tabular}{|l|c|c|}
\hline \multicolumn{1}{|c|}{ Penyaluran Dana } & Persentase & Jumlah \\
\hline Dana Sosial & $30 \%$ & Rp. $30.000 .000,-$ \\
\hline Pinjaman Produktif & $70 \%$ & Rp. $70.000 .000,-$ \\
\hline Total & $100 \%$ & Rp. $100.000 .000,-$ \\
\hline
\end{tabular}

Sumber: Bank Syariab Mandiri Cabang Lombok Timur 


\section{Deskripsi Modal Awal Usaha Nasabah}

Deskripsi Modal Awal Usaha Nasabah sebelum mendapatkan pinjaman, ratarata dari nasabah responden sudah memiliki modal usaha sendiri. Tabel berikut ini adalah gambaran kepemilikan modal usaha sendiri:

Tabel 3 Jumlah Modal Usaha Nasabah Sebelum Mendapat Pembiayaan

\begin{tabular}{|c|c|c|}
\hline No & Jenis Usaha & $\begin{array}{c}\text { Jumlah } \\
\text { Modal Sendiri }\end{array}$ \\
\hline 1 & Usaha Dagang & $\begin{array}{ll}\mathrm{Rp} & 700.000\end{array}$ \\
\hline 2 & Usaha Dagang & Rp 2.000 .000 \\
\hline 3 & Usaha Dagang & Rp 2.000 .000 \\
\hline 4 & Usaha Dagang & Rp 2.000 .000 \\
\hline 5 & Usaha Dagang & Rp 2.000 .000 \\
\hline 6 & Usaha Dagang & Rp 2.000 .000 \\
\hline 7 & Usaha Dagang & Rp 5.000 .000 \\
\hline 8 & Usaha Dagang & Rp 10.000 .000 \\
\hline 9 & Usaha Dagang & $\mathrm{Rp} \quad 500.000$ \\
\hline 10 & Usaha Dagang & $\mathrm{Rp} \quad 500.000$ \\
\hline 11 & Usaha Kue & Rp 4.000 .000 \\
\hline 12 & Usaha Kue & Rp 2.000 .000 \\
\hline 13 & Usaha Kue & Rp 2.000 .000 \\
\hline 14 & Usaha Kue & Rp 2.000 .000 \\
\hline 15 & Usaha Kue & Rp 2.000 .000 \\
\hline 16 & Usaha Sayuran & 500.000 \\
\hline 17 & Usaha Sayuran & 500.000 \\
\hline 18 & Usaha Sayuran & 300.000 \\
\hline 19 & Usaha Sayuran & 300.000 \\
\hline 20 & Usaha Sayuran & 500.000 \\
\hline & Rata-rata & Rp 2.040 .000 \\
\hline
\end{tabular}

umber : diolah dari wawancara dan dokumentasi 
Berdasarkan tabel di atas dapat diketahui bahwa nasabah usaha dagang, usaha kue dan usaha sayuran, rata-rata sudah mempunyai modal sendiri yang umumnya bervariasi. Untuk modal awal tertinggi adalah sebesar Rp. 10.000.000,-. Sedangkan modal awal terendah adalah sebesar Rp. 300.000,-. Dengan kata lain bahwa rata-rata kepemilikan modal sendiri untuk usaha dagang, usaha kue dan usaha sayuran adalah sebesar Rp. 2.040.000,-.

\section{Deskripsi Jenis Usaha dan Jumlah Pinjaman}

Untuk penyaluran dana Qardhul hasan, Bank Syariah Mandiri Cabang Lombok Timur telah mendistribusikan bantuan dalam berbagai macam jenis usaha. Jenis usaha tersebut diantaranya adalah : Usaha Dagang, Usaha Kue dan Usaha Sayuran. Dalam penelitian ini, data responden yang diambil sebanyak 20 nasabah responden yang tersebar di sekitar wilayah Kota Lombok Timur sesuai dengan kebijakan BSM yang membatasi nasabah untuk pembiayaan Qardhul hasan tidak lebih dari 20 nasabah. Diketahui bahwa semua jenis usaha responden mendapatkan bantuan berupa dana tambahan modal untuk usaha. Usaha responden di antaranya adalah usaha dagang sebanyak 10 orang, usaha kue sebanyak 5 orang dan usaha sayuran sebayak 5 orang.

Tabel 4 Jenis Usaha Nasabah

\begin{tabular}{|c|c|}
\hline Jenis Usaha & Jumlah Nasabah \\
\hline Usaha Dagang & 10 \\
\hline Usaha Kue & 5 \\
\hline Usaha Sayuran & 5 \\
\hline
\end{tabular}

Adapun besaran pemberian pinjamana Dana Qardhul hasan, Bank Syariah Mandiri Cabang Lombok Timur memberikan dana kepada nasabah berdasarkan pada tingkat kebutuhan mereka serta berdasarkan jenis usaha yang dijalani. Pada tabel di bawah ini, kita melihat bahwa semua nasabah membutuhkan tambahan modal, Bank Syariah Mandiri Cabang Lombok Timur memberikan rata-rata sebesar Rp. 
1.300.000,- tambahan modal untuk semua jenis usaha. Pinjaman tertinggi adalah sebesar Rp. 2.000.000,- dan pinjaman terendah adalah sebesar Rp. 500.000,-.

Tabel 5 Jumlah Pinjaman Dana Qardhul hasan

\begin{tabular}{|c|c|c|}
\hline No & Jenis Usaha & $\begin{array}{l}\text { Jumlah } \\
\text { Pinjaman }\end{array}$ \\
\hline 1 & Usaha Dagang & $\mathrm{Rp} \quad 2.000 .000$ \\
\hline 2 & Usaha Dagang & $\mathrm{Rp} \quad 2.000 .000$ \\
\hline 3 & Usaha Dagang & Rp 2.000 .000 \\
\hline 4 & Usaha Dagang & Rp 2.000 .000 \\
\hline 5 & Usaha Dagang & Rp $\quad 500.000$ \\
\hline 6 & Usaha Dagang & Rp 1.500 .000 \\
\hline 7 & Usaha Dagang & Rp 2.000 .000 \\
\hline 8 & Usaha Dagang & Rp 1.500 .000 \\
\hline 9 & Usaha Dagang & Rp 2.000 .000 \\
\hline 10 & Usaha Dagang & Rp 1.000 .000 \\
\hline 11 & Usaha Kue & Rp 2.000 .000 \\
\hline 12 & Usaha Kue & Rp 2.000 .000 \\
\hline 13 & Usaha Kue & Rp 1.000 .000 \\
\hline 14 & Usaha Kue & Rp 1.000 .000 \\
\hline 15 & Usaha Kue & Rp 1.000 .000 \\
\hline 16 & Usaha Sayuran & $\mathrm{Rp} \quad 500.000$ \\
\hline 17 & Usaha Sayuran & $\mathrm{Rp} \quad 500.000$ \\
\hline 18 & Usaha Sayuran & $\mathrm{Rp} \quad 500.000$ \\
\hline 19 & Usaha Sayuran & $\mathrm{Rp} \quad 500.000$ \\
\hline 20 & Usaha Sayuran & 500.000 \\
\hline & Rata-rata & Rp 1.300 .000 \\
\hline
\end{tabular}

Sumber: diolah dari angket wawancara dan dokumentasi 


\section{Deskripsi Perubahan Modal Usaha Nasabah}

Perubahan modal usaha adalah gambaran tentang total modal usaha yang dimiliki oleh nasabah responden setelah mendapatkan pinjaman dari Bank Syariah Mandiri Cabang Lombok Timur. Berikut ini adalah tabel tentang perubahan modal usaha nasabah responden:

Tabel 6 Total Modal Usaha Nasabah

\begin{tabular}{|r|l|r|r|r|r|}
\hline $\begin{array}{c}\text { N } \\
\mathbf{0}\end{array}$ & Jenis Usaha & $\begin{array}{c}\text { Modal Awal } \\
\text { Usaha } \\
\mathbf{( R p )}\end{array}$ & $\begin{array}{c}\text { Jumlah } \\
\text { Pinjaman } \\
\mathbf{( R p )}\end{array}$ & $\begin{array}{c}\text { Total } \\
\text { Modal Usaha } \\
\mathbf{( R p )}\end{array}$ & $\begin{array}{c}\text { Peningatan } \\
\text { Jumlah } \\
\text { Modal } \\
\mathbf{( \% )}\end{array}$ \\
\hline $\mathbf{1}$ & Usaha Dagang & 700.000 & 2.000 .000 & 2.700 .000 & $74 \%$ \\
\hline $\mathbf{2}$ & Usaha Dagang & 2.000 .000 & 2.000 .000 & 4.000 .000 & $50 \%$ \\
\hline $\mathbf{3}$ & Usaha Dagang & 2.000 .000 & 2.000 .000 & 4.000 .000 & $50 \%$ \\
\hline $\mathbf{4}$ & Usaha Dagang & 2.000 .000 & 2.000 .000 & 4.000 .000 & $50 \%$ \\
\hline $\mathbf{5}$ & Usaha Dagang & 2.000 .000 & 500.000 & 2.500 .000 & $20 \%$ \\
\hline $\mathbf{6}$ & Usaha Dagang & 2.000 .000 & 1.500 .000 & 3.500 .000 & $43 \%$ \\
\hline $\mathbf{7}$ & Usaha Dagang & 5.000 .000 & 2.000 .000 & 7.000 .000 & $28 \%$ \\
\hline $\mathbf{8}$ & Usaha Dagang & 10.000 .000 & 1.500 .000 & 11.500 .000 & $13 \%$ \\
\hline $\mathbf{9}$ & Usaha Dagang & 500.000 & 2.000 .000 & 2.500 .000 & $80 \%$ \\
\hline $\mathbf{1 0}$ & Usaha Dagang & 500.000 & 1.000 .000 & 1.500 .000 & $66 \%$ \\
\hline $\mathbf{1 1}$ & Usaha Kue & 4.000 .000 & 2.000 .000 & 6.000 .000 & $33 \%$ \\
\hline $\mathbf{1 2}$ & Usaha Kue & 2.000 .000 & 2.000 .000 & 4.000 .000 & $50 \%$ \\
\hline $\mathbf{1 3}$ & Usaha Kue & 2.000 .000 & 1.000 .000 & 3.000 .000 & $33 \%$ \\
\hline $\mathbf{1 4}$ & Usaha Kue & 2.000 .000 & 1.000 .000 & 3.000 .000 & $33 \%$ \\
\hline $\mathbf{1 5}$ & Usaha Kue & 2.000 .000 & 1.000 .000 & 3.000 .000 & $33 \%$ \\
\hline $\mathbf{1 6}$ & Usaha Sayuran & 500.000 & 500.000 & 1.000 .000 & $50 \%$ \\
\hline $\mathbf{1 7}$ & Usaha Sayuran & 500.000 & 500.000 & 1.000 .000 & $50 \%$ \\
\hline $\mathbf{1 8}$ & Usaha Sayuran & 300.000 & 500.000 & 800.000 & $62 \%$ \\
\hline $\mathbf{1 9}$ & Usaha Sayuran & 300.000 & 500.000 & 800.000 & $50 \%$ \\
\hline $\mathbf{2 0}$ & Usaha Sayuran & 500.000 & 500.000 & 1.000 .000 & $\mathbf{4 6 \%}$ \\
\hline & Rata-rata & $\mathbf{2 . 0 4 0 . 0 0 0}$ & $\mathbf{1 . 3 0 0 . 0 0 0}$ & $\mathbf{3 . 3 4 0 . 0 0 0}$ & \\
\hline & Sumber: & & & \multicolumn{1}{c}{$\%$} \\
\hline
\end{tabular}

Sumber: diolah dari wawancara dan dokumentasi 
Berdasarkan tabel di atas diketahui bahwa untuk usaha dagang, usaha kue dan usaha sayuran terjadi perubahan modal usaha nasabah responden yaitu adanya peningkatan jumlah modal usaha dengan rata-rata sebesar Rp. 3.340.000,- atau sebesar rata-rata 46\%. Adapun total modal usaha tertinggi adalah sebesar Rp. 11.500.000,- atau terjadi peningkatan sebesar 13\% dari total modal. Untuk total modal terendah adalah sebesar Rp. 800.000,- atau terjadi peningkatan modal usaha sebesar $62 \%$ dari total modal.

\section{Deskripsi Periode Usaha Berjalan Setelah Pembiayaan}

Periode usaha berjalan ini menggambarkan aktivitas suatu usaha yang dilakukan setelah mendapatkan pinjaman. Pengukuran rentan waktu berjalannya usaha dilakukan berdasarkan waktu sejak menerima pinjaman sampai dengan dilakukan penelitian yaitu per 10 November 2020. Berikut ini tabel periode berjalan usaha nasabah responden:

\section{KESIMPULAN}

Pelaksanaan pembiayaan Qardhul hasan di Bank Syariah Mandiri Cabang Lombok Timur diaplikasikan dalam program yang disebut dengan Program Mitra Umat yaitu : Program Didik Umat (Pemberdayaan Ekonomi) dan Simpati Umat (Kepedulian Sosial), dalam pengembangannya mencakup kegiatan ekonomi produktif maupun konsumtif, sosial kemasyarakatan meliputi pendidikan, kesehatan. Secara garis besar program ini terbagi dalam kegiatan pemberdayaan ekonomi (diwujudkan dalam bentuk pemberian pinjaman Qardhul hasan berupa modal usaha atau investasi dan konsumtif) dan kegiatan sosial (sumbangan). Dalam proses pelaksanaan pemberian pembiayaan ini Bank Syariah Mandiri Cabang Lombok Timur banyak memberikan kemudahan-kemudahan terutama dalam proses pengajuan dan pembayaran angsuran, sehingga nasabah merasa nyaman dengan pelayanan pembiayaan ini. Akan tetapi, pembiayaan ini hanya diberikan kepada calon nasabah yang mempunyai kepercayaan yang tinggi serta kemauan dan kemampuan. Sedangkan 
untuk pengawasan, Bank Syariah Cabang Lombok Timur lebih mengutamakan pada jalinan komunikasi intensif.

Prinsip dasar pembiayaan Qardbul hasan Bank Syariah Mandiri (BSM) Cabang Lombok Timur adalah rasa kepedulian, tanggung jawab serta kewajiban untuk mendistribusikan harta kekayaan dari orang-orang kaya kepada orang-orang yang membutuhkan. Sejak awal tahun 2008, Bank Syariah Mandiri Cabang Lombok Timur telah menyalurkan dana Qardbul hasan senilai Rp. 55.500.000,- kepada 50 nasabah sampai dengan 10 Maret 2011. Untuk sumber dana, Bank Syariah Mandiri Cabang hanya mendapatkan dana dari Lembaga Amil Zakat BSM Umat Kantor Pusat. Sedangkan untuk alokasi penyaluran pembiayaan, Bank Syariah Mandiri Cabang Lombok Timur menetapkan sebesar 70\% untuk usaha produktif dan 30\% untuk sumbangan sosial. Penyaluran dana Qardhul hasan untuk usaha produktif, Bank Syariah Mandiri Cabang Lombok Timur menetapkan pembagiannya kepada empat dari delapan asnaf yaitu fakir, miskin, gharimin, dan riqab. Sedangkan penyaluran dana Qardhul hasan untuk sumbangan sosial bank menetapkan pembagiannya hanya kepada fi sabilillah, ibnu sabil dan muallaf. Pelaksanaan pembiayaan Qardhul hasan di BSM kota Lombok Timur sudah sesuai dengan syariah dan ketentuan dan persyaratan DSN.

Kontribusi dana Qardhul hasan bagi Usaha Mikro nasabah adalah adanya peningkatan pendapatan yang rata-ratanya adalah sebesar Rp. 400.000,- atau sekitar 66\%. Dengan adanya kenaikan pendapatan ini berpengaruh terhadap meningkatnya pendapatan bersih (setelah dipotong angsuran) para nasabah yang sebelumnya hanya memperoleh pendapatan rata-rata sebesar Rp. 505.000,- menjadi rata-rata sebesar Rp. 775.000 ,- perbulan. Dengan adanya peningkatan pendapatan usaha sebesar $66 \%$ berarti pembiayaan Qardhul hasan telah memberikan kontribusi sebesar Rp. 235.000,atau 18\% kepada masyarakat miskin untuk berada diatas batas garis kemiskinan yang menurut Bank Dunia yaitu penghasilan sebesar Rp. 540.000,- per orang per bulan. Selain pendapatan nasabah responden mengalami peningkatan, modal usaha juga mengalami peningkatan. Bagi usaha Dagang, Kue dan Sayuran, modal usaha secara keseluruhan rata-rata meningkat menjadi Rp. 3.340.000, atau mengalami peningkatan sebesar 46\%. Terjadinya peningkatan modal usaha ini tentu juga akan berpengaruh terhadap meningkatnya jumlah aset usaha yang sebelumnya hanya rata-rata Rp. $2.040 .000,-\cdot$ 


\section{DAFTAR PUSTAKA}

Ali, Mohammad Daud, Sistem Ekonomi Islam: Zakat dan Wakaf. Cetakan 1. Jakarta: UI Press, 2006.

Antonio, Muhammad Syafi'i. Bank Syariah. Jakarta: Gema Insani Press, 2000.

Arifin, Zainul. Dasar-Dasar Manajemen Bank Syariah. Cetakan 3. Jakarta: Pustaka Alvabet, 2005.

Departemen Agama Republik Indonesia, Al-Quran dan Terjemahnya, Yogyakarta: PT. Dana Bhakti Wakaf, 1992.

Ensiklopedi Hukum Islam, (Jakarta: PT. Ichtiar Baru Van Hoeve).

Gie, Kwik Kian. Praktek Bisnis dan Orientasi Ekonomi Indonesia, Jakarta: PT Gramedia Pustaka Utama \& Sekolah Tinggi Ilmu Ekonomi IBII, 1998.

Hafiduddin, Didin. Zakat dalam Perekonomian Modern, cet. 1, Jakarta: Gema Insani Press, 2002.

Karim, Adiwarman A. Bank Islam: Analisis Fiqih dan Kenangan. Cetakan 1. Jakarta: IIIT Indonesia, 2003.

Marbun, B.N. Manajemen Perusahaan Kecil, Jakarta: PustakaBinaman Pressindo, 1996.

Moleong, Lexy J. Metodologi Penelitian Kualitatif, Edisi Revisi, Bandung: Rosda Karya, 2007.

Rahardjo, Dawam M. Islam dan Transformasi Soaial-Ekonomi, Jakarta: Lembaga Studi Agama dan Filsafat, (LSAF), 1999

Supardi, Metodologi Penelitian Ekonomi Bisnis, Yogyakarta: UII Press, 2005.

Suryabrata, Sumadi. Metodologi Penelitian, Jakarta: RajaGrafindo Persada, 1997.

Tunggal, Amin Widjaja. Corporate Social Responcibility, Jakarta: Harvindo, 2008.

Umar, Husein. Metode Riset Bisnis, Jakarta: PT. Gramedia Pustaka Utama, 2003.

Yahya, Rizal. Aji Erlangga, Ahim Abdurrahim, Akuntansi Perbankan Syariah Teori dan Praktik Kontemporer, Jakarta: Salemba Empat, 2009.

Yuliadi, Imamudin. Ekonomi Islam Sebuah Pengantar. Cet. I. Yogyakarta: LPPI, 2001. 